\title{
O CÓDIGO CIVIL BRASILEIRO NA DISCIPLINA DA PESQUISA COM SERES HUMANOS
}

Brazilian Civil Code in the area of research on human subjects

${ }^{1}$ Universidade de São Paulo. São Paulo/SP, Brasil.

Correspondência: Eduardo Tomasevicius Filho.E-mail: tomasevicius@usp.br.

Recebido em: 29/12/2014. Revisado em: 26/05/2015. Aprovado em: 02/06/2015. 


\section{RESUMO}

Este artigo tem por objetivo relacionar as normas éticas sobre pesquisas com seres humanos com o Código Civil brasileiro, lei que trata de diversos aspectos relacionados à proteção da pessoa humana. Em geral, os pesquisadores da área médica desconhecem a legislação civil, não se dando conta das consequências jurídicas dos erros causados pelas pesquisas realizadas. Apresenta-se, no início, um resumo da disciplina ética sobre pesquisas com seres humanos, com o Código de Nuremberg e a Declaração de Helsinque, além da disciplina infralegal no Brasil, realizada pelo Conselho Nacional de Saúde. Em seguida, com o intuito de demonstrar a inexistência de um vazio legislativo nessa matéria, analisaram-se os aspectos do Código Civil relativos às pesquisas com seres humanos, como a personalidade jurídica, a capacidade de agir, os direitos da personalidade e a responsabilidade civil.

\section{Palavras-Chave}

Direitos da Personalidade; Pesquisas com Seres Humanos; Responsabilidade Civil.

\section{ABSTRACT}

This study seeks to relate the ethical norms for research on human subjects with Brazilian Civil Code, a law that considers many aspects of protection for individuals. In general, medical researchers are unaware of civil legislation and do not realize the legal consequences of any errors caused by their research. First, a summary of the ethical aspect of research on human subjects is presented, along with the Nuremberg Code and the Declaration of Helsinki, as well as the non-statutory aspect of Brazilian law, which is performed by the Brazilian National Health Council. Second, to demonstrate the inexistence of a lack of legislative consistency in this area, the study analyzes the aspects of Civil Code relative to research on human subjects, as well as legal status, the ability to act, rights to legal status, and civil liability.

\section{Keywords}

Legal Status Rights; Research on Human Subjects; Civil Liability. 


\section{Introdução}

Pesquisas com seres humanos vivos são realizadas diariamente. Sem elas, não seria possível o desenvolvimento da medicina e de áreas afins. Os resultados delas são divulgados todos os dias nos meios de comunicação, trazendo a esperança para a cura de doenças, ao mesmo tempo em que algumas dessas pesquisas trazem desinformação para a maior parte da população - quando alertam, por exemplo, que o consumo de determinado alimento é a causa de determinada doença e, tempos depois, anunciam que esse mesmo alimento é benéfico para a cura de outra doença, ou, ainda, nos casos em que se publicam pesquisas que estabeleceram nexos causais notadamente insustentáveis, com dados recolhidos em amostras inadequadas ou insuficientes para chegarem a determinada conclusão. Embora as pesquisas sejam feitas há muito tempo, somente a partir do século XIX foram adotadas metodologias científicas. No século XX, passaram a ser realizadas amplamente com a participação das universidades e indústrias farmacêuticas ${ }^{1}$, ensejando a regulamentação dessa atividade.

Em nível internacional, a regulamentação das pesquisas com seres humanos deu-se com o denominado Código de Nuremberg ${ }^{2}$, além da Declaração de Helsinque, cuja primeira versão é de 1964 e a última versão, de 2013. Esta Declaração vem sofrendo enormes críticas por não refletir mais os valores adotados em suas primeiras versões, permitindo que interesses econômicos prevaleçam sobre a bioética, o que prejudica os participantes das pesquisas ou priva populações inteiras dos benefícios advindos desses estudos. Inclusive, o Brasil é um dos países mais críticos quanto a essa flexibilização normativa ${ }^{3}$.

Em nível interno, a regulamentação das pesquisas com seres humanos está em resolução do Conselho Nacional de Saúde (Resolução CNS n. 446/20124), que é ato infralegal - o que pode enfraquecê-la em razão do princípio da legalidade, previsto na Constituição Federal de $1988\left(\mathrm{CF} / 88^{5}\right)$, segundo o qual "ninguém é obrigado a fazer ou a deixar de fazer alguma coisa senão em virtude de lei" (artigo $5^{\circ}$, inciso II). Até o presente momento, não existe no Brasil uma lei específica sobre pesquisas com seres humanos. Foram propostos na Câmara dos Deputados os Projetos de Lei

${ }^{1}$ GARRAFA, Volnei; LORENZO, Claudio. Helsinque 2008: redução da proteção e maximização de interesses privados. Revista da Associação Médica Brasileira, São Paulo, v. 55, n. 5. p. 514, set./out. 2009. Disponível em: <http://repositorio.unb.br/bitstream/10482/12650/1/ARTIGO_Helsinque2008Reducao.pdf>. Acesso em: 21 set. 2015.

2 CÓDIGO DE NUREMBERG. Disponível em: <http://bvsms.saude.gov.br/bvs/publicacoes/codigo_nuremberg.pdf>. Acesso em: 21 set. 2015.

${ }^{3}$ GARRAFA, Volnei. Declaración de Helsinki y sus repetidos 'ajustes': un tema fatigoso. Revista Lassalista de Investigación, Caldas, v. 11, n. 1, p. 38, jan./jun. 2014. Disponível em: <http://www.scielo.org.co/pdf/rlsi/ v11n1/v11n1a04.pdf>. Acesso em: 22 set. 2015.

${ }^{4}$ BRASIL. Conselho Nacional de Saúde. Resolução n. 466, de 12 de dezembro de 2012. Disponível em: <http://www.conselho.saude.gov.br/resolucoes/2012/Reso466.pdf>. Acesso em: 22 set. 2015.

${ }^{5}$ BRASIL. Constituição da República Federativa do Brasil de 1988. Disponível em: <http://www.planalto.gov. br/ccivil_03/constituicao/ConstituicaoCompilado.htm>. Acesso em: 16 set. 2015. 
n. $7.086 / 2002^{6}$ e $2.473 / 2003^{7}$, ambos arquivados. No Senado Federal, foi proposto o Projeto de Lei n. 78/2006 ${ }^{8}$, arquivado em 2014, e, recentemente, o Projeto de Lei n. $200 / 2015^{9}$, em tramitação, bastante criticado pela Sociedade Brasileira de Bioética $^{10}$. Ante esse quadro normativo, pode-se imaginar a existência de uma lacuna legal na disciplina da pesquisa com seres humanos no Brasil.

No entanto, o Código Civil brasileiro trata de diversos assuntos diretamente relacionados a esse tema, em termos de personalidade e capacidade, autonomia, relações familiares e responsabilidade civil. Assim, o objetivo deste texto é analisar a aplicação do Código Civil brasileiro às pesquisas com seres humanos, pois, por ser lei, sua observância é obrigatória a todos, independentemente de qualquer regulamentação interna ou internacional sobre o tema. $\mathrm{Na}$ elaboração deste texto, usaram-se fontes históricas - especificamente o "Julgamento de Nuremberg" -, a Declaração de Helsinque em suas diversas versões, além do próprio Código Civil brasileiro e as resoluções do Conselho Nacional de Saúde. Também foram usadas referências bibliográficas do campo da bioética e do direito civil.

\section{Pesquisas com seres humanos: normas éticas e infralegais}

A elaboração normativa acerca das pesquisas com seres humanos foi feita com maior destaque em momentos trágicos do século $\mathrm{XX}$, notadamente no pós-Segunda Guerra Mundial em resposta às atrocidades praticadas durante o regime nazista, ainda que não tenham sido as únicas realizadas antes e depois do conflito. Naquela época, médicos alemães realizaram experiências com prisioneiros de campos de concentração, contaminando-os intencionalmente com vírus, inoculando-os com substâncias, submetendo-os a transplantes de ossos e a situações limítrofes de temperatura e de pressão. Levados a julgamento pelas potências vencedoras, eles alegaram em suas defesas que os experimentos foram realizados em

\footnotetext{
${ }^{6}$ BRASIL. Câmara dos Deputados. Projeto de Lei n. 7.086/2002. Dispõe sobre Diretrizes e Normas Regulamentadoras de Pesquisas envolvendo Seres Humanos. Disponível em: <http://www.camara.gov.br/proposicoesWeb/fichadetramitacao?idProposicao=63954>. Acesso em: 22 set. 2015.

${ }^{7}$ BRASIL. Câmara dos Deputados. Projeto de Lei n. 2.473/2003. Dispõe sobre Diretrizes e Normas Regulamentadoras de Pesquisas envolvendo Seres Humanos. Disponível em: <http://www.camara.gov.br/proposicoesWeb/fichadetramitacao?idProposicao=142406>. Acesso em: 22 set. 2015.

${ }^{8}$ BRASIL. Senado Federal. Projeto de Lei n. 78, de 2006. Estabelece punições para as violações às diretrizes e normas concernentes às pesquisas que envolvem seres humanos e determina a corresponsabilidade do pesquisador, do patrocinador e da instituição pela indenização devida aos sujeitos das pesquisas por eventuais danos ou prejuizos. Disponivel em: <http://www.senado.gov.br/atividade/materia/detalhes. asp?p_cod_mate=77271>. Acesso em: 22 set. 2015.

${ }^{9}$ BRASIL. Senado Federal. Projeto de Lei n. 200, de 2015. Dispõe sobre a pesquisa clínica. Disponível em: <http://www.senado.leg.br/atividade/materia/detalhes.asp?p_cod_mate=120560>. Acesso em: 22 set. 2015. ${ }^{10}$ SOCIEDADE BRASILEIRA DE BIOÉTICA. Projeto de Lei do Senado n. 200, de 2015. Retira da sociedade brasileira o controle das pesquisas envolvendo seres humanos. Disponível em: <http://www.sbbioetica. org.br/noticia/projeto-de-lei-do-senado-no-200-de-2015-retira-da-sociedade-brasileira-o-controle-das-pesquisas-envolvendo-seres-humanos/>. Acesso em: 22 set. 2015.
} 
legítima defesa (artigo 53, Código Penal alemão) por estarem em estado de emergência nacional provocado pela guerra, com o intuito de que os resultados dessas pesquisas fossem usados em benefício dos soldados alemães em combate. Esses médicos foram condenados e, na sentença, elencaram-se dez princípios a respeito de pesquisas com seres humanos, que se tornaram conhecidos como Código de Nuremberg. Em breve síntese, esses princípios consagram a imprescindibilidade do consentimento da pessoa que participa do experimento e que as pesquisas devem ser feitas para a produção de vantagens para a sociedade, evitando-se sofrimento desnecessário. Tampouco se deve gerar risco de morte ou de invalidez permanente, salvo se o pesquisador participar do experimento. Além disso, devem-se testar previamente os experimentos em animais ou usar os conhecimentos já existentes acerca de determinada doença para poupar a saúde dos participantes. Assegura-se o direito da pessoa de se retirar do experimento, e o pesquisador deve interromper a investigação se houver a suspeita de que o prosseguimento nela provocará danos aos participantes ${ }^{11}$.

Tendo como ponto de partida as regras listadas em Nuremberg, a Associação Médica Mundial lançou a Declaração de Helsinque sobre "Princípios éticos para a pesquisa médica envolvendo seres humanos", promulgada em 1964 e atualizada diversas vezes - sendo a última revisão em 2013, em congresso realizado na cidade de Fortaleza. Seu texto original ${ }^{12}$ refletia muito do que estava no Código de Nuremberg, de modo a reforçar, desde logo, a ideia de que nenhum médico estaria isento de responsabilidades civil, criminal e ética em seus países. Nela consta também a missão do médico, que é a de resguardar a saúde da população, e que pesquisas clínicas devem ser realizadas de acordo com princípios morais e científicos, além de deverem ser embasadas em experimentos laboratoriais ou em uso prévio em animais. Outro aspecto importante é que pesquisas são de total responsabilidade dos pesquisadores - jamais de seus participantes - e que devem sempre ser realizadas por pessoas qualificadas sob a supervisão de profissionais da área médica. Nelas, devem ser considerados os riscos, inclusive devendo-se alertar os participantes a esse respeito e interromper a investigação quando os resultados obtidos possam causar danos aos mesmos. Também consta a preocupação quanto a participantes de determinada pesquisa estarem em estado de dependência em face do pesquisador, e é destacada a necessidade de obtenção de consentimento por escrito não apenas dos capazes, mas também dos incapazes, por meio de seus representantes legais, assegurando-se, ademais, o direito do participante de retirar-se do estudo.

\footnotetext{
${ }^{11}$ NUREMBERG MILITARY TRIBUNALS.Trials of War Criminals before the Nuremberg Military Tribunals under Control Council Law n. 10. Volume II - "The medical case", "The Milch Case". Washington: Superintendent of Documents. U.S. Government Printing Office. 1949. P. 5; 14; 182-183; 193-197 Disponivel em: <http://www.loc.gov/rr/frd/Military_Law/pdf/NT_war-criminals_Vol-II.pdf>.

${ }^{12}$ ASSOCIAÇÃO MÉDICA MUNDIAL. Declaração de Helsinque - I. Disponível em: <http://www.ufrgs.br/bioetica/helsin1.htm>. Acesso em: 22 set. 2015.
} 
Na revisão de $1975^{13}$, houve importantes aperfeiçoamentos na realização de pesquisas com seres humanos. Declarou-se, nesse contexto, que a finalidade de uma pesquisa médica com seres humanos era o aperfeiçoamento dos diagnósticos, procedimentos terapêuticos e profiláticos e a compreensão da etiologia e patologia das doenças. Acrescentou-se que as pesquisas devem ser alicerçadas não apenas em experimentos prévios com animais, mas também na literatura científica existente, a fim de que sejam iniciadas mediante apresentação de projeto de pesquisa a ser apreciado por uma comissão independente. Estabeleceu-se que a proteção do participante da pesquisa prevalece sobre o interesse da sociedade e da ciência na realização do estudo, razão pela qual se reconheceu a necessidade de cuidados para que a pesquisa não viole a privacidade de seus participantes, bem como sua personalidade e sua integridade física e psíquica. Estatuiu-se o dever de que os resultados divulgados sejam exatos, incluindo o uso de grupo de controle, e que pesquisas realizadas em desacordo com os princípios da declaração não podem ser admitidas para publicação. Em $1983^{14}$, acrescentou-se o dever de proteção ao meio ambiente e a preocupação com o bem-estar dos animais usados como cobaias, bem como o dever dos pesquisadores de obter o consentimento não apenas dos representantes legais de pessoas que participam da pesquisa, mas também das próprias crianças.

Já no fim da década de 1980, evidenciava-se a preocupação com os conflitos de interesses entre as atividades meramente acadêmicas e a indústria farmacêutica, já que esta é quem financia a maior parte das pesquisas. Havia o risco de as investigações serem conduzidas com preponderância das leis do mercado, e não das normas morais. Nesse sentido, em $1989^{15}$, inseriu-se a regra segundo a qual as comissões de ética em pesquisa devem ter atuação independente em relação aos patrocinadores e pesquisadores.

Desde a década de 1990, diversos estudiosos latino-americanos da bioética, assim como órgãos de classe e governos da região, têm demonstrado graves preocupações com os rumos que a Declaração de Helsinque tomou desde então, o que a teria feito perder a autoridade da qual gozava para a regulamentação de pesquisas com seres humanos, ao ceder cada vez mais aos interesses da indústria farmacêutica, atuante em escala transnacional ${ }^{16}$. Entre essas preocupações, destacam-se aquelas referentes ao uso inadequado do placebo em pesquisas médicas para as quais já existe tratamento disponível - o que faria todos os participantes dessas

\footnotetext{
${ }^{13}$ ASSOCIAÇÃO MÉDICA MUNDIAL. Declaração de Helsinque - Il. Disponível em: <http://www.ufrgs.br/bioeti$\mathrm{ca} /$ helsin2.htm>. Acesso em: 22 set. 2015.

${ }^{14}$ ASSOCIAÇÃO MÉDICA MUNDIAL. Declaração de Helsinque - III. Disponível em: <http://www.ufrgs.br/bioetica/helsin3.htm>. Acesso em: 22 set. 2015.

${ }^{15}$ ASSOCIAÇÃO MÉDICA MUNDIAL. Declaração de Helsinque - IV. Disponível em: <http://www.ufrgs.br/bioetica/helsin4.htm>. Acesso em: 22 set. 2015.

${ }^{16}$ GARRAFA, Volnei. op. cit. p. 36.
} 
pesquisas perderem a chance de restabelecer a saúde ${ }^{17}$. O segundo problema é o surgimento de um duplo standard de pesquisa, de modo que pesquisas realizadas em países ricos, cujas legislações são rígidas, sigam padrões severos de controle ético, enquanto pesquisas similares realizadas em países pobres, com legislações pouco rígidas e populações vulneráveis, na maior parte dos casos sem acesso a medicamentos, sejam realizadas de maneira antiética ou até mesmo proibidas nos países-sede dos grandes laboratórios ${ }^{18}$. Inclusive, se pretendia tolerar o oferecimento de tratamentos menos eficientes, sob a alegação de que tratamento melhor não estaria disponível em determinado país. O terceiro aspecto denunciado é a constante modificação da Declaração de Helsinque não apenas por razões técnicas, decorrentes do avanço da ciência, mas por se pretender flexibilizá-la por questões estritamente econômicas. Com isso, a internacionalização das pesquisas, em vez de beneficiar países pobres em termos de acesso a medicamentos, tem servido para a exploração de indivíduos e de populações inteiras, inclusive para se pularem etapas de estudos acerca dos medicamentos ${ }^{19}$.

Em $1996^{20}$, acabou-se regulamentando, na Declaração de Helsinque, o uso do placebo. Estabeleceu-se, nesse caso, o direito de cada paciente de receber o melhor diagnóstico e terapia dentro do estudo. Excepcionalmente, estudos com placebo poderiam ser desenvolvidos quando não houvesse métodos diagnósticos ou terapêuticos comprovados, justamente para não haver a perda da chance de tratamento.

No ano $2000^{21}$, acrescentaram-se novas regras: os métodos terapêuticos já desenvolvidos devem ser continuamente submetidos a novos experimentos e testes; os comitês de ética em pesquisa passam a ter a prerrogativa de controlar as pesquisas realizadas. Os pesquisadores devem comunicar todos os eventos adversos graves, bem como o nome dos financiadores, patrocinadores, afiliações institucionais, inclusive na divulgação dos estudos, com o intuito de reduzir os efeitos dos conflitos de interesse. Nessa reunião, tentou-se aprovar o uso de placebo mesmo quando existisse tratamento, mas ainda não disponível dentro do país ${ }^{22}$. No entanto, manteve-se o entendimento de que o placebo só poderia ser utilizado em estudos quando ainda não houvesse procedimentos preventivos, diagnósticos e terapêuticos comprovados. Em 2004, houve grande ataque à Declaração de

\footnotetext{
${ }^{17}$ SCHLEMPER JUNIOR, Bruno Rodolfo. 0 placebo e a Declaração de Pachuca: letras mortas? Revista Bioética, Brasília, v. 22, n. 1. p. 463. Disponível em: <http://www.scielo.br/pdf/bioet/v22n3/v22n3a10.pdf>. http://dx.doi.org/10.1590/1983-80422014223029.

${ }^{18}$ KOTTOW, Miguel. De Helsinki a Fortaleza: una Declaración dessangrada. Revista Bioética. Brasília, v. 22, n. 1. p. 29, abr. 2014. Disponível em: <http://revistabioetica.cfm.org.br/index.php/revista_bioetica/article/view/880/969>. Acesso em: 22 set. 2015.; GARRAFA, Volnei; LORENZO, Claudio. op. cit., p. 515.

${ }^{19}$ GARRAFA, Volnei; LORENZO, Claudio. op. cit., p. 514-515.

${ }^{20}$ ASSOCIAÇÃO MÉDICA MUNDIAL. Declaração de Helsinque - V. Disponível em: <http://www.ufrgs.br/bioetica/helsin5.htm >. Acesso em: 22 set. 2015.

${ }^{21}$ ASSOCIAÇÃO MÉDICA MUNDIAL. Declaração de Helsinque - VI. Disponível em: <http://www.ufrgs.br/bioetica/helsin6.htm>. Acesso em: 22 set. 2015.

${ }^{22}$ GARRAFA, Volnei; LORENZO, Claudio. op. cit., p. 516.
} 
Helsinque e os Estados Unidos retiraram sua adesão a ela, passando a seguir as Guidelines for Good Clinical Practice (GCP, diretrizes para boas práticas clínicas) ${ }^{23}$. A partir de então, as pesquisas norte-americanas passaram a seguir as normas internas daquele país ${ }^{24}$.

Em $2008^{25}$, em nova revisão da Declaração de Helsinque, adicionou-se o dever do médico de resguardar não apenas a saúde da população, mas também a dos participantes das pesquisas. Reconheceu-se a vulnerabilidade não apenas de indivíduos, mas de populações que participam das pesquisas, as quais devem ser realizadas somente quando houver probabilidade de a comunidade inteira beneficiar-se dos resultados. Previu-se a consulta a líderes comunitários ou a membros de família para a realização de pesquisas, sem prejuízo da obrigatoriedade de obtenção do consentimento individual de cada participante. Ampliou-se também a regulamentação ética não apenas para o estudo com pessoas, mas também com materiais humanos em biobancos ou biorrepositórios. Nesses casos, também se exige a obtenção do consentimento da pessoa, salvo quando isso for impossível ou impraticável, a critério do comitê de ética em pesquisa. Com o intuito de dar maior publicidade às pesquisas, todos os projetos submetidos aos comitês de ética em pesquisa devem ser registrados em banco de dados público, além de terem o dever de divulgar resultados inconclusivos. Ademais, inseriu-se o dever de indenizar os participantes de pesquisas quando estes sofrerem danos. Todavia, a grande discussão nessa assembleia foi novamente quanto ao uso do placebo ${ }^{26}$, ao se permitir o uso deste não apenas em casos nos quais ainda não exista "intervenção atualmente comprovada”, mas também quando, “(...) por razões metodológicas convincentes e cientificamente sólidas, o uso de placebo se faz necessário para determinar a eficácia ou segurança de uma intervenção e quando os pacientes que receberem placebo ou nenhum tratamento não estiverem sujeitos a qualquer risco de dano grave ou irreversível”. Assim, seria possível o uso de placebo mesmo em caso de tratamento existente.

Os países latino-americanos, contando com atuação destacada do Brasil, posicionavam-se contrários a esse tipo de flexibilização na Declaração de Helsinque ${ }^{27}$. A Rede Latino-Americana e Caribenha de Bioética da Unesco (Redbioética) emitiu a Declaração de Córdoba sobre Ética em Pesquisa com Seres Humanos, na qual se opôs às alterações da Declaração de Helsinque, propondo seguir em seu lugar a Declaração Universal sobre Bioética e Direitos Humanos, da Unesco ${ }^{28}$.

\footnotetext{
${ }^{23}$ KOTTOW, Miguel. op. cit.

${ }^{24}$ GARRAFA, Volnei; LORENZO, Claudio. op. cit., p. 516.

${ }^{25}$ ASSOCIAÇÃO MÉDICA MUNDIAL. Declaração de Helsinque - 2008. Disponível em: <http://www.icflab.com. $\mathrm{br} / \mathrm{site} /$ arquivos/downloads/declaracao-de-helsinque-da-associacao-medica-mundial-emenda-de-outubro-de-2008-1476015.pdf>. Acesso em: 22 set. 2015.

${ }^{26}$ GARRAFA, Volnei; LORENZO, Claudio. op. cit., p. 517.

${ }^{27}$ GARRAFA, Volnei. op. cit., p. 38.

${ }^{28}$ GARRAFA, Volnei; LORENZO, Claudio. op. cit., p. 517.
} 
Na última revisão da Declaração de Helsinque, em 2013, acrescentou-se o encorajamento para que profissionais de outras áreas também aderissem aos princípios desta, além do dever de apresentação de relatórios finais aos comitês de ética em pesquisa $^{29}$. No entanto, substituiu-se o termo "populações" por "grupos"30. Quanto ao uso de placebo, manteve-se redação favorável aos patrocinadores em detrimento dos participantes, ao se tolerar o uso do mesmo em casos em que se deseja usar uma “intervenção menos efetiva que a melhor comprovada" para determinar a eficácia ou segurança de uma intervenção - evitando-se, contudo, a exposição a riscos adicionais por não ter recebido a intervenção mais adequada.

A revisão de 2013 gerou muita polêmica no Brasil porque, surpreendentemente, o país anfitrião, que sempre teve atuação de destaque na luta contra a flexibilização das pesquisas, votou pela aprovação do texto que permitia o uso inadequado do placebo. Esse posicionamento gerou a reprovação generalizada dentro e fora do país, a começar pelo próprio Conselho Federal de Medicina, que discordava veementemente dessa mudança ${ }^{31}$. Naquele mesmo ano, foi emitida a Declaração de Pachuca, que rechaçou as alterações da Declaração de Helsinque e recomendou a reprovação de estudos que violem preceitos éticos, ainda que em conformidade com a referida declaração ${ }^{32}$. Inclusive, há pesquisadores que propõem a elaboração e adoção de normas latino-americanas sobre pesquisas com seres humanos ${ }^{33}$.

Já no Brasil ${ }^{34}$, as regras sobre pesquisas com seres humanos não estão reguladas por lei. Foram normatizadas sob a forma de ato infralegal, por meio de

${ }^{29}$ ASSOCIAÇÃO MÉDICA MUNDIAL. Declaração de Helsinque - 2013. Disponível em: <http://www.amb.org. br/_arquivos/_downloads/491535001395167888_DoHBrazilianPortugueseVersionRev.pdf>. Acesso em: 22 set. 2015.

${ }^{30}$ MILLUM, J; WENDLER, D; EMANUEL, E.J. The 50th Anniversary of the Declaration of Helsinki: progress but many remaining challenges. JAMA, v. 310, n. 20, p. 2143-2144, 27 nov. 2013. Disponível em: <http://jama.jamanetwork.com/article.aspx?articlelD=1760320>. doi:10.1001/jama.2013.281632.

${ }^{31}$ SCHLEMPER JUNIOR, Bruno Rodolfo. op. cit., p. 464. GARRAFA, Volnei. op. cit., p. 39.

${ }^{32}$ SCHLEMPER JUNIOR, Bruno Rodolfo. op. cit., p. 467.

${ }^{33}$ KOTTOW, Miguel. op. cit., p. 32.

${ }^{34} \mathrm{Em}$ se tratando de direito internacional, o Conselho da Europa aprovou em 1997 a Convenção para a Protecção dos Direitos do Homem e da Dignidade do Ser Humano face às Aplicações da Biologia e da Medicina - a qual não se aplica ao Brasil - e a Conferência Geral da Unesco em 2005 aprovou por unanimidade a Declaração Universal sobre Bioética e Direitos Humanos. No entanto, ambas as declarações reproduzem, em linhas gerais, as disposições da Declaração de Helsinque. De qualquer modo, podem-se destacar algumas disposições interessantes daquela Convenção, como o artigo 12, segundo o qual "não se poderá proceder a testes predictivos de doenças genéticas ou que permitam quer a identificação do indivíduo como portador de um gene responsável por uma doença quer a detecção de uma predisposição ou de uma susceptibilidade genética a uma doença, salvo para fins médicos ou de investigação e sem prejuízo de um aconselhamento genético apropriado", o artigo 18, segundo o qual “1 - quando a pesquisa em embriões in vitro é admitida em lei, esta garantirá uma proteção adequada do embrião; 2 - a criação de embriões humanos com fins de investigação é proibida" e o artigo 24 , segundo o qual "a pessoa que tenha sofrido um dano injustificado resultante de uma intervenção tem direito a uma reparação equitativa nas condições e de acordo com as modalidades previstas em lei". PORTUGAL. Gabinete de Documentação e Direito Comparado. Convenção para a Protecção dos Direitos do Homem e da Dignidade do Ser Humano face às Aplicações da Biologia e da Medicina. Disponível em: <http://www.gddc.pt/direitos-humanos/ textos-internacionais-dh/tidhregionais/convbiologiaNOVO.html>. Acesso em: 22 set. 2015. 
resoluções do Conselho Nacional de Saúde. A primeira delas foi a Resolução CNS n. 1/1988, que aprovou normas de pesquisa em saúde. Esta resolução foi revogada pela Resolução CNS n. 196/1996, que se tornou muito conhecida no meio acadêmico, até sua revogação pela atual Resolução CNS n. 466/2012.

Nos termos da Resolução CNS n. 466/2012, a realização de pesquisas envolvendo seres humanos só pode ser realizada mediante aprovação prévia de um protocolo de pesquisa por um Comitê de Ética em Pesquisa (CEP) de composição multiprofissional ${ }^{35}$. A autonomia da pessoa de participar ou não de uma pesquisa é registrada por meio da assinatura de um Termo de Consentimento Livre e Esclarecido (TCLE), no qual devem constar informações claras e relevantes acerca do objeto da pesquisa, seus benefícios, riscos e desconfortos, a gratuidade pela participação, o ressarcimento de despesas em que venha a incorrer, a garantia de reparação dos danos causados em sua execução e a faculdade de retirada imotivada do consentimento a qualquer tempo sem qualquer prejuízo a sua pessoa. Para os incapazes, do ponto de vista jurídico, registra-se a participação por meio de um Termo de Assentimento Livre e Esclarecido (TALE), em que se explica, em linguagem ainda mais acessível do que a habitual para adultos, o objeto da pesquisa, seus objetivos e de que maneira participará da mesma. Neste caso, os responsáveis legais do incapaz também manifestarão sua concordância com a participação na pesquisa por meio de um TCLE. Em comunidades indígenas ou naquelas em que a cultura grupal reconheça a autoridade de um líder ou do coletivo sobre o indivíduo, estabelece-se que se deve obter tanto o consentimento do líder como também de cada participante individualmente. Não se recomenda a realização de pesquisas com pessoas sob o poder de outra, como estudantes, militares, empregados, presidiários, internos, asilados e religiosos.

Ainda nos termos da Resolução CNS n. 466/2012, emprega-se o termo "participante da pesquisa", e não mais o termo "sujeito de pesquisa", para se afirmar com mais clareza a autonomia da pessoa. Do mesmo modo, não se fala mais em mero consentimento, mas sim em processo de consentimento livre e esclarecido, o qual se inicia com o convite para a participação no estudo e se formaliza com a assinatura do TCLE - e esse consentimento deve ser ratificado por aditamentos ou

\footnotetext{
${ }^{35}$ A Resolução CNS n. 466/2012 inseriu dispositivo pelo qual pretende submeter toda e qualquer pesquisa envolvendo seres humanos ao controle de comitês de ética em pesquisa. Trata-se de medida inconveniente e inconstitucional, porque a ideia dos comitês de ética em pesquisa é a de proteger os participantes de experimentos que coloquem em risco a vida, a integridade física e psíquica, ou que os submetam a dor, bem como a de colocá-los a salvo de experimentos desnecessários. Ao estender a obrigatoriedade de comitês de ética em pesquisa a todos os ramos do conhecimento, nisso se inserem as ciências sociais, as quais têm por objeto o desenvolvimento de teorias sobre o ser humano, apresentadas no plano das ideias e não no corpo das pessoas. Assim, esses comitês de ética em pesquisa em ciências sociais serão comitês de censura à livre manifestação do pensamento, sendo, portanto, inconstitucionais nos termos do artigo $5^{\circ}$, inciso IX, da CF/88: “IX - é livre a expressão da atividade intelectual, artística, científica e de comunicação, independentemente de censura ou licença". BRASIL. Constituição da República Federativa do Brasil de 1988, cit.
} 
pela submissão de um novo documento sempre que ocorrerem novas descobertas ou eventos adversos (casos fortuitos) na execução dos estudos.

Considerando-se que pesquisas com seres humanos no Brasil devem atender aos princípios de autonomia, não maleficência, beneficência, justiça e equidade, quaisquer eventos adversos que possam colocar em risco a vida ou a saúde dos participantes necessitam ser comunicados ao CEP e aos participantes da pesquisa, para readequação, suspensão ou interrupção do estudo. Exige-se que, quando o estudo puder resultar em danos ao feto, sejam fornecidos anticoncepcionais para mulheres. Também se impõe que os resultados das pesquisas sejam compartilhados com seus participantes e também com a coletividade, mediante comunicação de resultados das pesquisas para a melhoria da qualidade de vida. Deve-se assegurar que os resultados das pesquisas conduzidas no exterior ou em cooperação estrangeira sejam compartilhados com a população brasileira, por transferência de tecnologia e registro de novas drogas no Brasil. Exigem-se, ainda, a submissão de relatórios parciais e finais de pesquisa para apreciação do CEP que aprovou o estudo. Por fim, para se assegurar a publicidade, toda e qualquer pesquisa realizada no Brasil fica registrada na denominada "Plataforma Brasil", disponível na internet para consulta por qualquer interessado ${ }^{36}$.

\section{0 código civil na disciplina das pesquisas com seres humanos}

Com o descrédito que a Declaração de Helsinque vem sofrendo nos últimos anos, bem como o fato de a disciplina referente a pesquisa com seres humanos no Brasil ser regulamentada por resolução (que é ato infralegal), pode-se imaginar que os participantes estão desamparados em caso de danos advindos de ações ou omissões. Porém, é preciso saber que os ordenamentos jurídicos têm leis que são suficientes para a proteção da pessoa humana que participa de pesquisas e que estabelecem deveres e responsabilidades para os pesquisadores. No caso brasileiro, a principal lei do ordenamento jurídico abaixo da Declaração de Helsinque é o Código Civil (Lei n. 10.406/2002 $2^{37}$ ), o qual constitui a "espinha dorsal" do ordenamento jurídico.

Um código civil é uma lei ampla, que contém milhares de artigos - no caso brasileiro, 2.028 artigos - e que trata de assuntos da vida privada das pessoas, como as obrigações e os contratos, a responsabilidade civil e o valor das indenizações, a posse, propriedade e outros assuntos relacionados às coisas, as questões relativas à família e às heranças, além de tratar dos direitos da pessoa humana e da prática de atos decorrentes do exercício de sua autonomia ${ }^{38}$. Cabe destacar

${ }^{36}$ BRASIL. Plataforma Brasil. Disponível em: <http://aplicacao.saude.gov.br/plataformabrasil/login.jsf>. Acesso em: 22 set. 2015.

${ }^{37}$ BRASIL. Lei Federal n. 10.406, de 10 de janeiro de 2002. Institui o Código Civil. Disponível em: <http://www.planalto.gov.br/ccivil_03/leis/2002/L10406.htm>. Acesso em: 22 set. 2015.

${ }^{38}$ Ademais, no caso brasileiro, o Código Civil também disciplina a atividade empresarial. 
que o Código Civil é de observância obrigatória por todas as pessoas, pois, nos termos da $\mathrm{CF} / 88$, "ninguém é obrigado a fazer ou a deixar de fazer algo senão em virtude de lei" (artigo 5 ${ }^{\circ}$, inciso II). Logo, independentemente do disposto na Declaração de Helsinque e na Resolução CNS n. 466/2012, não se pode contrariar ou afastar o que o Código Civil dispõe sobre essa matéria. Daí a importância de os pesquisadores com seres humanos conhecerem, em linhas gerais, como essa proteção se realiza na prática.

Em um ordenamento jurídico, existem basicamente quatro fontes de normas jurídicas: (a) a legal, emanada dos parlamentos; (b) a jurisprudencial, emanada dos tribunais; (c) a costumeira, gerada pelas práticas sociais imemoriais; $\mathrm{e}$ (d) a negocial, gerada pela manifestação da vontade livre de uma pessoa. Em se tratando de fonte negocial, a norma jurídica criada por esse meio denomina-se negócio jurídico, em que se destacam o testamento (manifestação de vontade de uma pessoa quanto ao destino de seus bens após sua morte), o casamento (manifestação de vontade entre duas pessoas com o intuito de formalizarem a constituição de uma família) e o contrato (manifestação de vontade entre duas pessoas com o intuito de criarem obrigações de natureza patrimonial). A pessoa, quando manifesta livremente sua vontade, cria para si uma norma jurídica, que se torna obrigatória e, portanto, juridicamente exigível.

O principal aspecto a ser considerado em uma pesquisa com seres humanos é a manifestação da vontade para a participação nela. Nos últimos tempos, com o despertar da atenção dos juristas para questões relativas à manifestação de vontade em temas voltados à própria pessoa humana, discute-se o uso do negócio jurídico para a disciplina de assuntos de natureza existencial. O primeiro exemplo são as diretivas antecipadas de vontade, conhecidas também como "testamento vital", que seria a possibilidade do uso do testamento para formalizar a manifestação de vontade de uma pessoa quanto ao seu próprio destino ${ }^{39}$. O segundo caso é aquele referente ao TCLE, documento pelo qual se registra a vontade livre de uma pessoa para que esta concorde com sua participação em determinada pesquisa. Poder-se-ia pensar que se trata de espécie de contrato, já que há duas partes - pesquisador e participante -, além de a manifestação livre da vontade ser exigida como requisito de validade. Todavia, não é um contrato porque seu objeto versa sobre assuntos de natureza não-patrimonial, como a vida e a integridade física e psíquica do participante da pesquisa. Entretanto, é um negócio jurídico, tal como o contrato, o testamento e o casamento: uma vez celebrado, cria obrigações ao pesquisador de proteger o participante da pesquisa.

\footnotetext{
${ }^{39}$ No Brasil, são disciplinadas pela Resolução CFM n. 1.995/2012. BRASIL. Conselho Federal de Medicina. Resolução n. 1.995, de 31 de agosto de 2012. Dispõe sobre as diretivas antecipadas de vontade dos pacientes. Disponível em: < http://www.portalmedico.org.br/resolucoes/CFM/2012/1995_2012.pdf>. Acesso em: 22 set. 2015.
} 
O artigo 104 do Código Civil brasileiro elenca os requisitos de validade de um negócio jurídico, que são aplicáveis a um TCLE:

Art. 104. A validade do negócio jurídico requer:

I - agente capaz;

II - objeto lícito, possível, determinado ou determinável;

III - forma prescrita ou não defesa em lei.

\section{Capacidade para participação em pesquisas}

De acordo com o primeiro requisito do artigo 104 do Código Civil, a validade do negócio jurídico TCLE exige capacidade do agente. A regra geral é que pessoas são juridicamente capazes, por exemplo, para participação em pesquisas, ao completarem 18 anos de idade (artigo 5, Código Civil), salvo se tiverem sido emancipadas.

No direito brasileiro, consideram-se como absolutamente incapazes as pessoas entre zero e 16 anos (artigo $3^{\circ}$, Código Civil), devendo ser representadas por seus representantes legais; já as pessoas relativamente capazes (artigo $4^{\circ}$, Código Civil) são aquelas que têm entre 16 e 18 anos, sendo, neste caso, assistidas por seus representantes legais. A diferença entre um caso e outro é que os representantes legais realizam o ato em nome do absolutamente incapaz, enquanto, em relação aos relativamente incapazes, apenas auxiliam o menor na realização do ato.

Os representantes legais dos menores de 18 anos são seus pais ou responsáveis, de acordo com Código Civil, que dispõe competir aos pais, quanto à pessoa dos filhos menores: "representá-los, até os dezesseis anos, nos atos da vida civil, e assisti-los, após essa idade, nos atos em que forem partes, suprindo-lhes o consentimento" (artigo 1.634, inciso V). O Código Civil aboliu a figura do pátrio poder - que era o poder do pai de decidir os destinos dos membros da família - para inserir o poder familiar - exercido por ambos os pais em igualdade de condições (artigo 1.631). Com o princípio da igualdade entre os cônjuges e companheiros nas relações familiares (artigo $5^{\circ}$, caput, inciso I, CF/ $/ 88^{40}$ ) os conflitos ora sufocados pela exclusividade da decisão paterna assumiram novos contornos. Em se tratando da participação de menores de idade em pesquisas, são comuns as divergências entre pais no caso de um deles não concordar com a participação do menor no estudo. Para que o pesquisador tenha segurança jurídica, é imprescindível a obtenção de dois TCLEs para a realização do estudo, sendo um assinado pelo pai e outro, pela mãe. É dispensável

\footnotetext{
40 “Art. $5^{\circ}$ - Todos são iguais perante a lei, sem distinção de qualquer natureza, assegurando-se aos brasileiros e aos estrangeiros residentes no País a inviolabilidade do direito à vida, à liberdade, à igualdade, à segurança e à propriedade, nos termos seguintes: I - homens e mulheres são iguais em direitos e obrigações, nos termos desta Constituição". BRASIL. Constituição da República Federativa do Brasil de 1988, cit.
} 
um dos TCLEs nas seguintes hipóteses previstas pelos artigos 1.635 e seguintes do Código Civil, entre outras: (a) falecimento do outro genitor; (b) desaparecimento comprovado ("pai ou mãe em lugar incerto e não sabido"); (c) condenação por crime cuja pena seja superior a dois anos de prisão; e (d) suspensão ou extinção do poder familiar por decisão judicial.

A guarda é a autorização conferida pelo juiz para que se regule o exercício de fato do poder familiar sobre os menores, inclusive para que a pessoa maior de idade não seja acusada do crime de subtração de incapazes (artigo 249, Código Penal ${ }^{41}$ ). O guardião - que pode ser, por exemplo, um parente como a avó, o irmão etc. - tem poderes de assistência material, moral e educacional em benefício do menor e pode, inclusive, opor-se aos pais durante seu exercício, nos termos do artigo 33, caput e parágrafo $2^{\circ}$ do Estatuto da Criança e do Adolescente (ECA, Lei Federal n. 8.069/1990 ${ }^{42}$ ). A dispensa do TCLE de ambos os pais nesse caso suscita dúvidas porque, numa interpretação literal, o ECA confere poderes de assistência acima apontados, mas não o de participação em pesquisas clínicas. Todavia, a interpretação razoável é de que basta o consentimento de quem tiver a guarda, pois, se houve perda ou suspensão do poder familiar, isso se deveu a desrespeito ao princípio do melhor interesse da criança. Assim, por exemplo, se a guarda está com a avó, é juridicamente irrelevante a concordância de toda e qualquer pessoa, pois o conflito potencial existe apenas entre o guardião e qualquer dos pais, e não entre o guardião e demais parentes.

Já a capacidade dos indígenas, nos termos do artigo $4^{\circ}$, parágrafo único, do Código Civil, é disciplinada por lei especial. Nesse caso, aplica-se a Lei Federal n. $6.001 / 1973^{43}$, conhecida como Estatuto do Índio, que estabelece um regime de tutela (artigos $7^{\circ}$ a 11) para os indígenas não integrados à denominada "comunhão nacional”. Essa tutela é exercida pela Fundação Nacional do Índio (Funai), nos termos do artigo $1^{\circ}$, inciso I, alínea “a”, da Lei Federal n. 5.371/1967 ${ }^{44}$. Dessa maneira, toda pesquisa que envolver índios ou comunidades indígenas requer a manifestação de vontade da Funai para sua validade, além do TCLE do líder indígena e de cada um dos participantes.

Desde a Antiguidade, os portadores de enfermidades mentais (furiosi, dementes e mentecapti em latim) eram considerados incapazes ${ }^{45}$. Esse entendimento era

\footnotetext{
${ }^{41}$ BRASIL. Decreto-Lei n. 2.848, de 07 de dezembro de 1940. Código Penal. Disponível em: <http://www. planalto.gov.br/ccivil_03/decreto-lei/Del2848compilado.htm>. Acesso em: 22 set. 2015.

${ }^{42}$ BRASIL. Lei Federal n. 8.069, de 13 de julho de 1990. Dispõe sobre o Estatuto da Criança e do Adolescente e dá outras providências. Disponível em: < http://www.planalto.gov.br/ccivil_03/LEIS/L8069.htm>. Acesso em: 22 set. 2015.

${ }^{43}$ BRASIL. Lei Federal n. 6.001, de 19 de dezembro de 1973. Dispõe sobre o Estatuto do Índio. Disponível em: <http://www.planalto.gov.br/ccivil_03/Leis/L6001.htm>. Acesso em: 22 set. 2015.

${ }^{44}$ BRASIL. Lei Federal n. 5.371, de 05 de dezembro de 1967. Autoriza a instituição da "Fundação Nacional do Índio" e dá outras providências. Disponível em: <http://www.planalto.gov.br/ccivil_03/leis/1950-1969/ L5371.htm>. Acesso em: 22 set. 2015.

${ }^{45}$ ALVES, José Carlos Moreira. Direito romano. 14. ed. Rio de Janeiro: Forense, 2007. p. 133.
} 
adotado pela legislação brasileira desde o século XIX. O Código Civil de 2002, por exemplo, ainda seguia esse entendimento, ao definir como absolutamente incapazes: "os que, por enfermidade ou deficiência mental, não tiverem o necessário discernimento para a prática desses atos" (artigo $3^{\circ}$, inciso II) e "os que, mesmo por causa transitória, não puderem exprimir sua vontade" (artigo $3^{\circ}$, inciso III). Também definia como relativamente incapazes: "os ébrios habituais, os viciados em tóxicos e os que, por deficiência mental, tenham o discernimento reduzido" (artigo $4^{\circ}$, inciso II); "os excepcionais, sem desenvolvimento mental completo" (artigo $4^{\circ}$, inciso III) e "os pródigos" (artigo $4^{\circ}$, inciso IV). Essas pessoas podiam ser interditadas, e cabia aos curadores o exercício da representação legal ou da assistência na prática de atos da vida civil.

No entanto, a Lei Federal n. 13.146/2015 ${ }^{46}$, que instituiu o Estatuto da Pessoa com Deficiência, em suas disposições finais, alterou substancialmente o regime das capacidades, ao revogar os incisos II e III do artigo $3^{\circ}$ e os incisos II, III e IV do artigo $4^{\circ}$ do Código Civil. Dessa forma, os portadores de deficiência mental e os pródigos não são mais considerados incapazes. Foram mantidos como relativamente incapazes apenas os ébrios habituais e os viciados em tóxicos, e transformados de absolutamente incapazes em relativamente incapazes "aqueles que, por causa transitória ou permanente, não puderem exprimir sua vontade".

Assim, os portadores de enfermidade ou de deficiência mental passam, agora, a ser considerados juridicamente capazes para a prática de atos da vida civil, conforme disposto no artigo $6^{\circ}$ do Estatuto da Pessoa com Deficiência ${ }^{47}$, e não estão mais sujeitos a curatela, porque se revogou expressamente essa possibilidade prevista no artigo 1.767 do Código Civil.

Ademais, o mesmo Estatuto prevê a necessidade de obtenção de TCLE do participante da pesquisa que seja portador de deficiência, conforme segue:

Art. 12. O consentimento prévio, livre e esclarecido da pessoa com deficiência é indispensável para a realização de tratamento, procedimento, hospitalização e pesquisa científica.

$\$ 1^{\circ}$ Em caso de pessoa com deficiência em situação de curatela, deve ser assegurada sua participação, no maior grau possível, para a obtenção de consentimento.

\footnotetext{
${ }^{46}$ BRASIL. Lei Federal n. 13.146, de 06 de julho de 2015. Institui a Lei Brasileira de Inclusão da Pessoa com Deficiência (Estatuto da Pessoa com Deficiência). Disponível em: <http://www.planalto.gov.br/ccivil_03/_ Ato2015-2018/2015/Lei/L13146.htm>. Acesso em: 22 set. 2015.

47 “Art. $6^{\circ}$ - A deficiência não afeta a plena capacidade civil da pessoa, inclusive para: I - casar-se e constituir união estável; II - exercer direitos sexuais e reprodutivos; III - exercer o direito de decidir sobre o número de filhos e de ter acesso a informações adequadas sobre reprodução e planejamento familiar; IV - conservar sua fertilidade, sendo vedada a esterilização compulsória; V - exercer o direito à família e à convivência familiar e comunitária; e VI - exercer o direito à guarda, à tutela, à curatela e à adoção, como adotante ou adotando, em igualdade de oportunidades com as demais pessoas". BRASIL. Lei Federal n. 13.146, de 06 de julho de 2015, cit.
} 
$\S 2^{\circ}$ A pesquisa científica envolvendo pessoa com deficiência em situação de tutela ou de curatela deve ser realizada, em caráter excepcional, apenas quando houver indícios de benefício direto para sua saúde ou para a saúde de outras pessoas com deficiência e desde que não haja outra opção de pesquisa de eficácia comparável com participantes não tutelados ou curatelados.

Entretanto, o portador de enfermidade ou deficiência mental poderá lavrar um termo para a denominada "tomada de decisão assistida”, prevista no novo artigo 1.783-A, caput e parágrafos do Código Civil. Esse procedimento consiste em a pessoa com deficiência eleger "[...] pelo menos duas pessoas idôneas, com as quais mantenha vínculos e que gozem de sua confiança, para prestar-lhe apoio na tomada de decisão sobre os atos da vida civil, fornecendo-lhes os elementos e informações necessários para que possa exercer sua capacidade". Resta saber de que maneira as pessoas portadoras de enfermidade ou de deficiência mental terão o necessário discernimento para lavrar o termo de "tomada de decisão assistida” não apenas para a participação em pesquisas, mas também para a realização dos demais atos da vida civil.

\section{A pesquisa como objeto jurídico}

O objeto do negócio jurídico intitulado TCLE é a realização de pesquisas com seres humanos, o que poderá afetar a vida e a integridade física e psíquica dos participantes da pesquisa. É imprescindível, portanto, a observância da licitude dessa prática, para que a pesquisa não seja considerada juridicamente inválida nem eticamente reprovável. A disciplina da proteção da pessoa humana enquanto ser existente está no capítulo referente aos direitos da personalidade (artigos 11 a 21, Código Civil). Conforme Bittar, "consideram-se como da personalidade os direitos reconhecidos à pessoa humana tomada em si mesma e em suas projeções na sociedade, previstos no ordenamento jurídico exatamente para a defesa de valores inatos do homem, como a vida, a higidez física, a intimidade, a honra, a intelectualidade e outros tantos" 48 .

Os direitos da pessoa humana protegidos pelo Código Civil sob a terminologia de direitos da personalidade são: (a) direito à vida; (b) direito à integridade física; (c) direito ao nome; e (d) direito à integridade psíquica. Por sua vez, esses direitos compreendem a proteção da honra, da imagem e da vida privada. A CF/88 também assegura essa mesma proteção no artigo $5^{\circ}$, que trata dos direitos fundamentais. Destacam-se os seguintes incisos: "III - ninguém será submetido à tortura nem a tratamento desumano ou degradante"; "X - são invioláveis a intimidade, a vida privada, a honra e a imagem das pessoas, assegurado o direito a indenização pelo dano material ou moral decorrente de sua violação".

\footnotetext{
${ }^{48}$ BITTAR, Carlos Alberto. Os direitos da personalidade. 5. ed. atual. e aum. por Eduardo C. B. Bittar. Rio de Janeiro: Forense Universitária, 2001. p. 1.
} 
Nessa parte, o pesquisador deve tomar muitos cuidados, porque a regra geral a respeito dos direitos da personalidade está no artigo 11 do Código Civil, com a seguinte redação: "Com exceção dos casos previstos em lei, os direitos da personalidade são intransmissíveis e irrenunciáveis, não podendo o seu exercício sofrer limitação voluntária”, em notória inspiração na obra de um dos precursores da matéria, de Cupis ${ }^{49}$. Com isso, mesmo que o participante da pesquisa concorde com limitações referentes a sua vida e a sua integridade física ou psíquica, tudo isso é desprovido de valor legal e o pesquisador está sujeito à responsabilização civil e, dependendo do caso, criminal.

Veja-se, por exemplo, o artigo 13 do Código Civil, o qual dispõe que: "Salvo por exigência médica, é defeso o ato de disposição do próprio corpo, quando importar diminuição permanente da integridade física, ou contrariar os bons costumes" e o artigo 15, segundo o qual "ninguém pode ser constrangido a submeter-se, com risco de vida, a tratamento médico ou a intervenção cirúrgica”. Pela interpretação desses dois artigos, o participante da pesquisa está legalmente proibido de concordar com pesquisas que possam causar-lhe danos, isto é, não se admite consentimento do ofendido como exclusão de ilicitude do ato, assim como o pesquisador não pode obrigar o participante a participar de determinado estudo, ainda que se pretenda com isso a preservação da vida. Se não se pode constranger pessoa alguma a participar de estudo - que pode ser um tratamento médico novo - quando isso importar risco de vida, com muito mais razão não se pode obrigar ninguém a participar quando isso não importar esse risco. O Código Civil, nos termos do artigo 14, apenas admite a disposição gratuita do próprio corpo, com objetivos científicos ou altruísticos, apenas após a morte da pessoa.

Do mesmo modo, a lei impede que a pessoa seja submetida a estudo em que se use placebo quando houver tratamento melhor já disponível, porque, nesse caso, o participante estaria limitando voluntariamente seu direito à vida e à integridade física, o que é proibido pelos artigos 11 e 13 do Código Civil. O TCLE, mesmo assinado pelo participante, será nulo de pleno direito. Ainda que no Brasil não exista tratamento disponível ou oferecido, essa limitação, antes de ser antiética, é ilegal. Em outras palavras, ainda que a Declaração de Helsinque esteja sendo flexibilizada, isso é juridicamente irrelevante e os responsáveis pela pesquisa, bem como seus patrocinadores, serão inevitavelmente responsabilizados juridicamente por essa prática.

Outro aspecto bastante importante é a proteção da vida privada da pessoa, que consiste no direito da pessoa de não ser importunada por terceiros ou de ser deixada a sós (right to be let alone) e também no direito a não interferência na tomada de certas decisões sobre sua vida privada (direito à autonomia), e ainda no direito de controlar quem terá acesso a informações sobre si mesma (informational

\footnotetext{
${ }^{49}$ DE CUPIS, Adriano. Os direitos da personalidade. 2. ed. São Paulo: Quorum, 2008. p. 51.
} 
privacy $)^{50}$. Nos termos do artigo 20 do Código Civil, “[a] vida privada da pessoa natural é inviolável, e o juiz, a requerimento do interessado, adotará as providências necessárias para impedir ou fazer cessar ato contrário a esta norma”.

Problemas envolvendo o direito à privacidade são comuns em pesquisas com seres humanos. Como regra geral, todos os dados coletados em pesquisas são confidenciais, justamente para a proteção da vida privada, imagem e honra dos participantes. Existem situações específicas bastante comuns, como as das pesquisas retrospectivas, realizadas por meio do acesso aos prontuários médicos. Considerando que esses documentos são de propriedade do potencial participante da pesquisa, e não do médico ou da instituição, o acesso às informações neles contidas requer autorização expressa do participante, sob pena de violação do direito à privacidade - porque a pessoa pode não concordar em participar da pesquisa ou que pessoas tenham acesso a essas informações, sendo indiferente o motivo da recusa.

Como se depreende do artigo 20 do Código Civil, caso esses dados sejam usados sem consentimento da pessoa - ou até mesmo em caso de mudança de opinião -, esta poderá requerer ao juiz que se interrompa tal prática ou que tais dados sejam incluídos do estudo. Por essa razão, não se devem usar dados sem que se obtenha tal consentimento do titular, devendo-se incluir no estudo apenas os dados de participantes que expressamente concordaram com seu uso. São ilegais certas interpretações do artigo IV, parágrafo $8^{\circ}$, da Resolução CNS n. 466/2012 $2^{51}$, de que o CEP pode dispensar o pesquisador de apresentar o TCLE ao participante da pesquisa retrospectiva quando este não for mais encontrado. É inadmissível que a análise da impossibilidade de localização da pessoa seja apriorística, dando-se por pressuposto que os interessados não serão mesmo encontrados, porque mudaram de endereço e não avisaram a instituição que detém seu prontuário médico - conduta inexigível por parte do participante da pesquisa, uma vez que, pelo princípio da legalidade, ninguém é obrigado a fazer ou a deixar de fazer alguma coisa senão em virtude de lei. Por isso, os pesquisadores não estão dispensados da entrega do TCLE. O correto é que o pesquisador envide os melhores esforços para a localização dos pacientes e que o CEP somente dispense a elaboração do TCLE em casos realmente excepcionais, quando for manifestamente impossível a localização dos potenciais participantes.

\footnotetext{
${ }^{50}$ FERREIRA RUBIO, Delia Matilde. El derecho a la intimidad: análisis del artículo 1071 bis del Código Civil a la luz de la doctrina, la legislación comparada y la jurisprudencia. Buenos Aires: Editorial Universidad, 1982. p. 42-44.

51 “Art. IV, § 8: Nos casos em que seja inviável a obtenção do Termo de Consentimento Livre e Esclarecido ou que esta obtenção signifique riscos substanciais à privacidade e confidencialidade dos dados do participante ou aos vínculos de confiança entre pesquisador e pesquisado, a dispensa do TCLE deve ser justificadamente solicitada pelo pesquisador responsável ao Sistema CEP/CONEP, para apreciação, sem prejuízo do posterior processo de esclarecimento". BRASIL. Conselho Nacional de Saúde. Resolução n. 466, de 12 de dezembro de 2012, cit.
} 
Existe ainda o risco de ocorrência de violação da imagem ou da honra da pessoa por meio da violação de sua privacidade, tanto em pesquisas retrospectivas como em pesquisas prospectivas, ao se divulgarem tais dados sem a autorização para esse fim. Também podem existir problemas referentes ao uso de imagens das pessoas em pesquisas, que podem ser tanto as de seu corpo como a dos exames sobre seu corpo. Nesse caso específico, a lei permite que a pessoa possa ceder, gratuita ou onerosamente, a exploração de sua imagem a terceiros. No entanto, essa imagem somente pode ser usada para as hipóteses com as quais expressamente concordou, não se admitindo interpretações extensivas de sua vontade.

A segunda situação é aquela referente ao acesso a materiais biológicos humanos depositados em biobancos ou em biorrepositórios ${ }^{52}$, regulamentados pela Resolução CNS n. 441/2011. Esta resolução estabelece que "o material biológico humano armazenado em biobanco ou biorrepositório é do sujeito da pesquisa, permanecendo sua guarda sob a responsabilidade institucional" (artigo 9o) e "o gerenciamento do material biológico humano armazenado em biobanco cabe à instituição e, no caso de biorrepositório, ao pesquisador responsável" (artigo 9º inciso I). Por isso, todo esse material pode ser armazenado apenas com consentimento do participante da pesquisa, formalizado por TCLE. Quando se tratar de biobanco, o artigo $5^{\circ}$ faculta à pessoa requerer a coleta de novo consentimento a cada uso do material ou dispensar previamente a instituição de solicitar novo consentimento para novas pesquisas. Já em se tratando de biorrepositórios, o artigo $6^{\circ}$ exige a formalização de novo TCLE para cada pesquisa a ser realizada com seu material biológico. Assim, nenhum pesquisador que tenha biorrepositório pode usar material biológico sem autorização prévia, sendo ilegal a alegação por parte do pesquisador de que o interessado encontra-se em local incerto e não sabido, bem como é ilegal a deliberação do CEP de dispensar tal formalização.

Considerando que os direitos da personalidade são intransmissíveis e irrenunciáveis nos termos do artigo 11 do Código Civil, a Resolução CNS n. 441/2011 dispõe que "o sujeito de pesquisa, ou seu representante legal, a qualquer tempo e sem quaisquer ônus ou prejuízos, pode retirar o consentimento de guarda e utilização do material biológico armazenado em biobanco ou biorrepositório, valendo a

\footnotetext{
52 “Art. $1^{\circ}, \S 1,1$ - Biobanco: coleção organizada de material biológico humano e informações associadas, coletado e armazenado para fins de pesquisa, conforme regulamento ou normas técnicas, éticas e operacionais pré-definidas, sob responsabilidade e gerenciamento institucional, sem fins comerciais; II - Biorrepositório: coleção de material biológico humano, coletado e armazenado ao longo da execução de um projeto de pesquisa específico, conforme regulamento ou normas técnicas, éticas e operacionais pré-definidas, sob responsabilidade institucional e sob gerenciamento do pesquisador, sem fins comerciais". BRASIL. Conselho Nacional de Saúde. Resolução n. 441, de 12 de maio de 2011. Dispõe sobre diretrizes para análise ética de pesquisas que envolvam armazenamento de material biológico humano ou uso de material armazenado em pesquisas anteriores. Disponivel em: <http://conselho.saude.gov.br/ resolucoes/2011/Reso441.pdf>. Acesso em: 22 set. 2015. Em outras palavras, biobanco é uma biblioteca de material biológico humano gerenciado por uma instituição e biorrepositório, uma coleção particular do pesquisador, constituída a partir de determinado projeto de pesquisa.
} 
desistência a partir da data de formalização desta" (artigo 10). No mesmo sentido, o Código Civil prevê a possibilidade de revogação, a qualquer tempo, da autorização para uso de seu corpo em pesquisas após sua morte. Logo, com muito mais razão se permite tal revogação enquanto estiver viva (artigo 14, parágrafo único).

\section{Pesquisas com embriões e fetos}

Duas outras situações que podem colocar em risco a vida e a saúde dos participantes da pesquisa são as pesquisas que envolvem embriões e gestantes. No primeiro caso, reacenderam-se discussões sobre a partir de qual momento inicia-se juridicamente a proteção da vida humana. Com o desenvolvimento das técnicas de reprodução assistida, não se sabe com certeza qual o melhor destino para os embriões excedentes: doá-los, guardá-los ou descartá-los. A primeira opção não oferece sérios problemas ético-jurídicos, porque equivale à adoção. Mas a segunda e terceira opções sofrem objeções, porque, de um lado, é inviável a manutenção desses embriões congelados indefinidamente; de outro lado, o descarte de embriões pode, de acordo com a concepção jurídica de vida adotada, representar sério problema, por ser considerado atentado à pessoa humana.

Existem correntes jurídicas a respeito do início da vida e, consequentemente, acerca do momento em que se reconhece a personalidade jurídica da pessoa humana, dotada de dignidade e protegida contra todo e qualquer atentado a sua existência. A primeira concepção é a concepcionista, segundo a qual há pessoa humana desde a fecundação do óvulo pelo sêmen humano. A segunda corrente é a natalista, segundo a qual somente há pessoa humana quando do nascimento com vida. Existe a terceira corrente, denominada teoria da personalidade condicionada, estabelecida no Código Civil, segundo a qual "a personalidade civil da pessoa começa do nascimento com vida; mas a lei põe a salvo, desde a concepção, os direitos do nascituro” (artigo 2º).

O resguardo dos direitos do nascituro voltava-se para questões envolvendo heranças, e não para a definição do início da proteção do nascituro contra atentados a sua existência. No entanto, a interpretação das normas jurídicas nessa matéria deve ser a mais ampla possível e, nesse sentido, a expressão "deixa a salvo, desde a concepção, os direitos do nascituro" incluiria o direito à vida e à integridade física. Esse entendimento de que se deve reconhecer o embrião como pessoa estaria consubstanciado pela Convenção Americana dos Direitos Humanos, de 1969, conhecida como Pacto de São José da Costa Rica e ratificada pelo Brasil em 1992 ${ }^{53}$. O Pacto adotou a concepção concepcionista, ao dispor que "[t] oda pessoa tem o direito de que se respeite sua vida. Esse direito deve ser protegido pela lei e, em geral, desde o momento da concepção. Ninguém pode ser privado da vida arbitrariamente" (artigo $4^{\circ}$, parágrafo $1^{\circ}$ ). Nos termos do artigo

\footnotetext{
${ }^{53}$ BRASIL. Decreto n. 678 , de 06 de novembro de 1992. Promulga a Convenção Americana sobre Direitos Humanos (Pacto de São José da Costa Rica), de 22 de novembro de 1969. Disponível em: <http://www.planalto.gov.br/ccivil_03/decreto/D0678.htm>. Acesso em: 22 set. 2015.
} 
5, parágrafo $3^{\circ}$, incluído na $\mathrm{CF} / 88$ em 2004 pela Emenda Constitucional n. 454, "[o] $s$ tratados e convenções internacionais sobre direitos humanos que forem aprovados, em cada Casa do Congresso Nacional, em dois turnos, por três quintos dos votos dos respectivos membros, serão equivalentes às emendas constitucionais".

No Brasil, essa matéria é disciplinada pela Resolução do Conselho Federal de Medicina n. 2.121/2015 $5^{55}$, que define regras éticas para utilização de técnicas de reprodução assistida. A resolução proíbe o uso destas técnicas para fins não reprodutivos, mas permite a seleção de embriões submetidos a diagnósticos de alterações genéticas causadoras de doenças. No tocante aos embriões produzidos em laboratório, a resolução estabelece que os embriões excedentes devem ser criopreservados, podendo ser descartados após cinco anos por manifestação de vontade dos pacientes, e que o tempo máximo de desenvolvimento de embriões in vitro será de 14 dias - justamente o tempo limite de divisão celular em que não se deu a formação do sistema nervoso do embrião. Sendo assim, o embrião é pessoa, tem dignidade e deve ter sua integridade física preservada, ainda que não seja um ser humano formado.

Nessa matéria, sempre haverá grande indagação ética, pois essas pesquisas estariam usando e sacrificando seres humanos vivos ${ }^{56}$. A Lei de Biossegurança (Lei n. $11.105 / 2005^{57}$ ) permitiu o uso de embriões em pesquisas com células-tronco, mas alguns de seus artigos foram objeto de ação direta de inconstitucionalidade

\footnotetext{
${ }^{54}$ BRASIL. Emenda Constitucional n. 45, de 30 de dezembro de 2014. Disponível em: <http://www.planalto. gov.br/ccivil_03/Constituicao/Emendas/Emc/emc45.htm>. Acesso em: 22 set. 2015.

${ }^{55}$ BRASIL. Conselho Federal de Medicina. Resolução n. 2.121, de 24 de setembro de 2015. Adota as normas éticas para a utilização das técnicas de reprodução assistida -sempre em defesa do aperfeiçoamento das práticas e da observância aos princípios éticos e bioéticos que ajudarão a trazer maior segurança e eficácia a tratamentos e procedimentos médicos - tornando-se o dispositivo deontológico a ser seguido pelos médicos brasileiros e revogando a Resolução CFM n 2.013/13, publicada no D.O.U. de 9 de maio de 2013, Seção I, p. 119. Disponível em: <http://www.portalmedico.org.br/resolucoes/CFM/2015/2121_2015.pdf>. Acesso em: 30 set. 2015.

${ }^{56}$ No Brasil é vedada a manipulação genética de seres humanos, inclusive de células-tronco. A antiga Lei de Biossegurança (Lei $n^{\circ} 8.974$, de 5 de janeiro de1995) e a nova Lei de Biossegurança (Lei $\left.n^{\circ} 11.105 / 2005\right)$ vedam tais práticas.

57 “Art. $5^{\circ}$ - É permitida, para fins de pesquisa e terapia, a utilização de células-tronco embrionárias obtidas de embriões humanos produzidos por fertilização in vitro e não utilizados no respectivo procedimento, atendidas as seguintes condições: I - sejam embriões inviáveis; ou II - sejam embriões congelados há 3 (três) anos ou mais, na data da publicação desta Lei, ou que, já congelados na data da publicação desta Lei, depois de completarem 3 (três) anos, contados a partir da data de congelamento. $\S 1^{\circ}$ Em qualquer caso, é necessário o consentimento dos genitores. $\S 2^{\circ}$ Instituições de pesquisa e serviços de saúde que realizem pesquisa ou terapia com células-tronco embrionárias humanas deverão submeter seus projetos à apreciação e aprovação dos respectivos comitês de ética em pesquisa. § $3^{\circ}$ É vedada a comercialização do material biológico a que se refere este artigo e sua prática implica o crime tipificado no art. 15 da Lei $n$. 9.434, de 4 de fevereiro de 1997. BRASIL. Lei Federal n. 11.105, de 24 de março de 2005. Regulamenta os incisos II, IV e V do § 10 do art. 225 da Constituição Federal, estabelece normas de segurança e mecanismos de fiscalização de atividades que envolvam organismos geneticamente modificados - OGM e seus derivados, cria o Conselho Nacional de Biossegurança - CNBS, reestrutura a Comissão Técnica Nacional de Biossegurança - CTNBio, dispõe sobre a Política Nacional de Biossegurança - PNB, revoga a Lei no 8.974, de 5 de janeiro de 1995, e a Medida Provisória no 2.191-9, de 23 de agosto de 2001, e os arts. 5o, 6o, 7o, 8o, 9o, 10 e 16 da Lei no 10.814, de 15 de dezembro de 2003, e dá outras providências. Disponível em: <http://www.planalto.gov.br/ccivil_03/_ato2004-2006/2005/lei//11105.htm>. Acesso em: 22 set. 2015.
} 
(ADI n. 3.510 ${ }^{58}$ ) no Supremo Tribunal Federal (STF) porque, no entender da Procuradoria-Geral da República, atentavam contra o direito à vida (artigo $5^{\circ}$, caput, $\mathrm{CF} / 88$ ) e contra a dignidade da pessoa humana (artigo $1^{\circ}$, inciso III, CF/88). Após anos de intensos debates em audiências públicas promovidas pelo STF, o julgamento final em 2008 foi pela autorização da realização dessas pesquisas, interpretando - em nosso entender, corretamente - o artigo $2^{\circ}$ do Código Civil, com os fundamentos de que não caberia ao STF decidir em que momento a vida se inicia nem se pesquisas com células-tronco adultas seriam mais vantajosas do que pesquisas com células-tronco embrionárias; tampouco não se poderia deixar de levar em conta que a Constituição de 1988 estabelece a liberdade, a segurança, o bem-estar, o desenvolvimento, a igualdade e a justiça. A proibição de pesquisas implicaria falta de apreço e de reverência por seres humanos que sofrem com as doenças das quais são portadores, além do fato de o texto constitucional dispor sobre a proteção à saúde e o incentivo da ciência. A realização de pesquisas com embriões in vitro não seria ato de desprezo ou de desrespeito aos mesmos, pois tais embriões não são pessoas, e sim apenas embriões de pessoas humanas - já que não têm as primeiras terminações nervosas, sem as quais não há como a vida humana se sustentar. Seria necessário, no entender do STF, distinguir a situação de que toda gestação advém de um embrião humano, mas nem todo embrião humano desencadeia uma gestação, sobretudo porque a opção pelas técnicas de reprodução assistida não impõe o dever de aproveitamento de todos os embriões eventualmente formados pela implantação no corpo feminino. Assim, o embrião pré-implantado é um bem jurídico protegido, mas não é uma pessoa humana. Logo, são lícitas no Brasil as pesquisas com células-tronco embrionárias.

O segundo caso refere-se à proteção do feto ou nascituro durante a gestação. Como, nesse caso, o próprio Código Civil dispõe que a lei põe a salvo, desde a concepção, os direitos do nascituro, toda pesquisa deve preocupar-se com a saúde da gestante, excluindo-a do estudo ou, conforme o caso, fornecendo-lhe anticoncepcionais para evitar malformação do feto por evento adverso desconhecido do pesquisador.

\section{A forma do TCLE}

Quanto à forma como requisito de validade do negócio jurídico, esta pode ser usada, na maior parte dos casos, para fins de prova (ad probationem) ou, quando for relevante no entender do legislador, servir como substância do ato (ad substantiam). Neste último caso, impõe-se a forma para chamar a atenção das partes para a importância do ato que realizam, bem como para fornecer informações relevantes, necessárias à manifestação da vontade livre e necessária para a formação

\footnotetext{
${ }^{58}$ SUPREMO TRIBUNAL FEDERAL. Ação Direta de Inconstitucionalidade n. 3.510. Disponível em: <http:// www.stf.jus.br/portal/jurisprudencia/listarConsolidada.asp?classe=ADI\&numero=3510\&origem=AP $>$. Acesso em: 22 set. 2015.
} 
do negócio jurídico. Em se tratando de TCLE, devido a sua importância, a normatização não se preocupa apenas com a forma, mas também com a formalização do negócio jurídico, que é o processo de consentimento do participante da pesquisa e que terá seu auge na assinatura do TCLE, o qual deve conter todas as informações previamente transmitidas oralmente ao participante da pesquisa.

Ao contrário do que dispunha a então Resolução CNS n. 196/1996 - que previa a forma do TCLE e considerava o consentimento livre e esclarecido apenas um ato -, a Resolução CNS n. 466/2012 agora leva em consideração os atos preparatórios para o registro desse consentimento livre e esclarecido. Nesse sentido, há claro paralelismo com o período de negociação de um contrato, o qual, ainda que não vincule as pessoas, é juridicamente relevante com fundamento no princípio da boa-fé. Logo, os pesquisadores estão sujeitos a este princípio, que impõe a conduta correta nas relações privadas, destacando-se os deveres de informação e de cooperação. Ainda que o TCLE não seja um contrato, a ele pode ser aplicada a disposição geral contida no artigo 422 do Código Civil, segundo o qual "os contratantes são obrigados a guardar, assim na conclusão do contrato, como em sua execução, os princípios de probidade e boa-fé". Também se aplica ao caso o artigo 187 do Código Civil, segundo o qual "também comete ato ilícito o titular de um direito que, ao exercê-lo, excede manifestamente os limites impostos pelo seu fim econômico ou social, pela boa-fé ou pelos bons costumes". Por essa razão, o participante deve ser muito bem informado e esclarecido sobre os objetivos da pesquisa da qual é convidado a participar.

Do ponto de vista prático, há muito que caminhar nesse quesito, pois, infelizmente, muitos pesquisadores ainda consideram o TCLE como mero entrave burocrático ao desenvolvimento da ciência, restando aos participantes da pesquisa a adesão aos experimentos mediante a mera assinatura desse documento sem prévia leitura. Existem estudos que comprovam a dificuldade dos participantes da pesquisa, por serem leigos ou por terem baixa escolaridade, de compreender os objetivos do estudo. Segue trecho de uma dissertação de mestrado que se voltou ao estudo do TCLE em ambiente hospitalar, na qual se denuncia o problema da incapacidade de se atingir o esclarecimento entre potenciais participantes de pesquisas:

Trata-se de um estudo transversal quantitativo com 399 sujeitos. A amostra foi intencional, selecionada entre usuários dos ambulatórios do Hospital das Clínicas da Faculdade de Medicina da Universidade de São Paulo. A coleta de dados utilizou um instrumento que continha um texto em prosa compatível para a avaliação das habilidades de leitura necessárias para a compreensão de um TCLE. Os dados apontam que mais de 46,6\% dos entrevistados foram classificados como analfabetos funcionais, destes, $12,7 \%$ sequer foram capazes de entender a tarefa proposta 
no texto lido. Apesar disto, quase $50 \%$ dos entrevistados declararam ter ao menos iniciado o ensino médio ${ }^{59}$.

Pelo que se observou, os participantes das pesquisas, mesmo que recebam as informações relevantes, são incapazes de compreendê-las, viciando seu consentimento. Ademais, é notório que os participantes de pesquisas estão em situação de vulnerabilidade em face do pesquisador. São diversas as razões para a ocorrência dessa situação, entre elas o temor reverencial despertado pelo profissional da saúde - o que, por si só, dificulta a possibilidade de autonomia do participante de questionar o objeto da pesquisa -, como também o fato de muitos participantes acreditarem que a participação em determinada pesquisa é condição para o prosseguimento do tratamento de sua saúde dentro do hospital universitário.

Também se realizou estudo similar entre 2009 e 2012 no município de Novo Oriente de Minas ( MG), em que foram apresentados dois TCLEs para leitura. Desse estudo participaram 125 pessoas, com idade média de 34,2 anos, predominantemente do sexo feminino e com escolaridade em nível fundamental. Mediante uso de escalas de dificuldade de leitura, chegou-se à conclusão de que os documentos são de difícil compreensão para seus leitores, sendo, portanto, inadequados para o propósito a que se prestam $^{60}$. Segundo os autores desse estudo, trata-se de uma prática de biopoder, porque o TCLE, em vez de ser usado para garantir a autonomia do participante, transforma-se em instrumento de dominação de populações vulneráveis, que estão em situação de assimetria em relação aos pesquisadores, o que pode ser um problema ético ${ }^{61}$. Para o Código Civil, essas práticas são consideradas defeitos do negócio jurídico, entre os quais o erro do participante da pesquisa, o dolo (mentira) do pesquisador, a coação (usar de ameaça para que se consinta com o TCLE) e o estado de perigo (concordar com o TCLE para evitar um mal maior), passíveis de anulação ${ }^{62}$.

${ }^{59}$ ARAUJO, Diego Vinicius Pacheco de. A caracterização do analfabetismo funcional em usuários do Hospital das Clínicas da Faculdade de Medicina da Universidade de São Paulo: recomendações para a redação do termo de consentimento livre e esclarecido. Dissertação (Mestrado) - Escola de Enfermagem da Universidade de São Paulo, São Paulo, 2009. p. 8.

${ }^{60}$ LOBATO, L.; CAÇADOR, B.; GAZZINELLI, M. Legibilidade dos termos de consentimento livre e esclarecido em ensaios clínicos. Revista Bioética, Brasília, v. 21, n. 3, p. 560, dez. 2013. Disponível em: <http://revistabioetica.cfm.org.br/index.php/revista_bioetica/article/view/777/939>. Acesso em: 21 set. 2015.

${ }^{61}$ Id. Ibid., p. 562.

${ }^{62} \mathrm{~A}$ título de exemplificação, o Código Civil dispõe sobre os defeitos do negócio jurídico nos artigos seguintes: "Art. 138. São anuláveis os negócios jurídicos, quando as declarações de vontade emanarem de erro substancial que poderia ser percebido por pessoa de diligência normal, em face das circunstâncias do negócio"; "Art. 145. São os negócios jurídicos anuláveis por dolo, quando este for a sua causa". "Art. 147. Nos negócios jurídicos bilaterais, o silêncio intencional de uma das partes a respeito de fato ou qualidade que a outra parte haja ignorado, constitui omissão dolosa, provando-se que sem ela o negócio não se teria celebrado". "Art. 151. A coação, para viciar a vontade, há de ser tal que incuta ao paciente fundado temor de dano iminente e considerável à sua pessoa, à sua família, ou aos seus bens"; "Art. 152. No apreciar a coação, ter-se-ão em conta o sexo, a idade, a condição, a saúde, o temperamento do paciente e todas as demais circunstâncias que possam influir na gravidade dela”. "Art. 156. Configura-se o estado de perigo quando alguém, premido da necessidade de salvar-se, ou a pessoa de sua família, de grave dano conhecido por outra parte, assume obrigação excessivamente onerosa". "Art. 157. Ocorre a lesão quando uma pessoa, sob premente necessidade, ou por inexperiência, se obriga a prestação manifestamente 


\section{A Responsabilidade civil dos pesquisadores}

Tanto a Declaração de Helsinque quanto a Resolução CNS n. 466/2012 estabelecem a indenização dos participantes de pesquisas com seres humanos em caso de danos à vida e à integridade física e psíquica. Inclusive, é exigido que o TCLE contenha disposição expressa sobre tal direito do participante e é proibido que se insiram cláusulas que exonerem ou limitem o pagamento de indenizações, sob a alegação de que o participante concordou com tal fato. Como advertiu Gogliano: "Portanto, aqueles que veem no consentimento informado uma possível exclusão de responsabilidade ou limitação a se refletir na reparação do dano, sob o pretexto de o doente assumir os riscos, estão a 'barganhar' com a responsabilidade civil" ${ }^{63}$.

Independentemente do que dizem as declarações éticas e os atos infralegais, interessa mesmo é o que o Código Civil dispõe sobre essa matéria. É imprescindível ter em mente que a vida, a integridade física e psíquica são direitos da personalidade e, portanto, são direitos indisponíveis - ou seja, intransmissíveis e irrenunciáveis, não podendo sofrer limitação voluntária. Ainda que o participante da pesquisa concorde em aceitar todos os termos e condições impostos pelo pesquisador, essa manifestação de vontade é simplesmente desconsiderada pelo direito civil. Por isso, não vale aqui a regra existente nos contratos acerca de sua força obrigatória, ou que pacta sunt servanda. Reputa-se ilícita a cláusula que estabelece a não indenização dos danos, porque, dessa maneira, atos ilícitos seriam legalizados. A título de exemplo, a Súmula n. $161^{64}$ do STF, editada em 1963 , estabeleceu que "em contrato de transporte, é inoperante a cláusula de não indenizar", justamente por envolver a vida e a integridade da pessoa. Essa cláusula transformou-se no artigo 734 do Código Civil: "o transportador responde pelos danos causados às pessoas transportadas e suas bagagens, salvo motivo de força maior, sendo nula qualquer cláusula excludente de responsabilidade". O segundo exemplo é a Súmula n. $130^{65}$ do Superior Tribunal de Justiça (STJ), segundo a qual "a empresa responde, perante o cliente, pela reparação de dano ou furto de veículo ocorridos em seu estacionamento", sendo nulos qualquer cláusula ou aviso para o cliente de que o estacionamento não se responsabiliza por danos ocorridos em suas dependências. Do mesmo modo, a Súmula n. $302^{66}$ do STJ define que "é abusiva a cláusula contratual de plano de saúde que limita no tempo a

desproporcional ao valor da prestação oposta". BRASIL. Lei Federal n. 10.406, de 10 de janeiro de 2002, cit.

${ }^{63}$ GOGLIANO, Daisy. O consentimento informado em matéria de bioética: ilusão de exclusão de responsabilidade. Revista da Faculdade de Direito da Universidade de São Paulo, v. 104, p. 543, jan./dez. 2009. Disponível em: <http://www.revistas.usp.br/rfdusp/article/view/67868>. http://dx.doi.org/10.11606/issn.2318-8235.v104i0p509-547.

${ }^{64}$ SUPREMO TRIBUNAL FEDERAL. Súmula $n$. 161. Disponível em: <http://www.stf.jus.br/portal/jurisprudencia/listarJurisprudencia.asp?s1=\%28\%28161\%2ENUME\%2E\%29\%29+NAO+S\%2EFLSV\%2E\&base=base Sumulas\&url=http://tinyurl.com/n2hjsyg>. Acesso em: 22 set. 2015.

${ }^{65}$ SUPERIOR TRIBUNAL DE JUSTIÇA. Súmula 130, SEGUNDA SEÇÃO, julgado em 29/03/1995, DJ 04/04/1995, p. 8294.

${ }^{66}$ SUPERIOR TRIBUNAL DE JUSTIÇA. Súmula 302, SEGUNDA SEÇÃO, julgado em 18/10/2004, DJ 22/11/2004, p. 425. 
internação hospitalar do segurado", não sendo possível, portanto, despejar pessoa internada do hospital ou interromper seu tratamento, ainda que ela tenha concordado com isso no contrato. Novamente, pelo fato de pesquisas com seres humanos envolverem direitos indisponíveis, o participante pode retirar-se do estudo, revogando sua manifestação de vontade, a qualquer tempo, sem qualquer justificativa.

Com o desenvolvimento das pesquisas gera novas informações previamente desconhecidas, mas que podem ser relevantes para o prosseguimento dos participantes na mesma, o consentimento precisa ser constante, para que o participante da pesquisa possa reavaliar a conveniência quanto ao prosseguimento no estudo, uma vez que o dever de informar decorre do princípio da boa-fé. Essa ideia também foi recepcionada, por analogia, da disciplina da revisão dos contratos por onerosidade excessiva, prevista no artigo 478 do Código Civil, que permite a resolução do contrato quando sua execução se tornar excessivamente onerosa ao devedor em razão de fatos supervenientes extraordinários e imprevisíveis. Essa mesma ideia está no artigo $6^{\circ}$, inciso V, do Código de Defesa do Consumidor ${ }^{67}$, que permite a "a modificação das cláusulas contratuais que estabeleçam prestações desproporcionais ou sua revisão em razão de fatos supervenientes que as tornem excessivamente onerosas". A onerosidade, no contexto de pesquisas com seres humanos, não é patrimonial, evidentemente. Trata-se de uma onerosidade em termos de assunção de riscos excessivos quanto à vida e à integridade física e psíquica do participante da pesquisa.

Quanto às despesas que o participante possa ter ao ingressar no estudo, em termos de gastos com transporte, alimentação e hospedagem, entre outros, o ressarcimento funda-se no artigo 884 do Código Civil, na parte que trata do enriquecimento sem causa, nos seguintes termos: "Aquele que, sem justa causa, se enriquecer à custa de outrem será obrigado a restituir o indevidamente auferido, feita a atualização dos valores monetários". Como, no Brasil, veda-se a remuneração do participante da pesquisa para evitar que sua participação no estudo seja interessada do ponto de vista financeiro, inexistirá justa causa para impor a assunção de tais despesas para a participação em determinado estudo.

Ademais, todo pesquisador que causar danos ao participante da pesquisa fica obrigado a repará-lo. É o que dispõe o Código Civil: "Aquele que, por ação ou omissão voluntária, negligência ou imprudência, violar direito e causar dano a outrem, ainda que exclusivamente moral, comete ato ilícito" (artigo 186) e "Aquele que, por ato ilícito (artigos 186 e 187), causar dano a outrem, fica obrigado a repará-lo" (artigo 927).

Esses danos não precisam sempre ser decorrentes de uma ação ou omissão diretas, mas podem vir da perda de uma chance de tratamento. Por exemplo,

\footnotetext{
${ }^{67}$ BRASIL. Lei Federal n. 8.078, de 11 de setembro de 1990. Dispõe sobre a proteção do consumidor e dá outras providências. Disponível em: <http://www.planalto.gov.br/ccivil_03/Leis/L8078compilado.htm>. Acesso em: 22 set. 2015.
} 
mesmo que o item 33 da Declaração de Helsinque, na versão de 2013, declare ser ético que, por "[...] razões metodológicas convincentes e cientificamente sólidas, o uso de qualquer intervenção menos efetiva que a melhor comprovada, o uso de placebo, ou de não intervenção, [seja] necessário para determinar a eficácia ou a segurança de uma intervenção", trata-se de ilícito civil e enseja reparação civil ou até mesmo ter repercussões na esfera criminal, por ser hipótese típica desse tipo de responsabilidade civil.

Como explicou Silva ${ }^{68}$, há situações em que a probabilidade é fundamental na solução do caso: quando a pessoa, por sua omissão, possa ter concorrido para não evitar prejuízo evitável ou reduzível, de modo que quem não agiu para evitar a perda da chance de outrem, quando podia tê-lo feito, fica obrigado a reparar o dano que aquela pessoa sofreu. Para Carnaúba, esse caso é hipótese de prejuízo-chance, decorrente de uma incerteza contrafactual ${ }^{69}$, que impede o causador do dano de fazer a contraprova. Os requisitos da responsabilidade por perda de uma chance foram colocados pelo autor:

Os casos de perda de chances são caracterizados pelos quatro elementos supramencionados: a preexistência de um interesse sobre um resultado aleatório; uma intervenção de um indivíduo, privando, no todo ou em parte, a vítima de suas chances de obter esse resultado aleatório desejado; o fim do processo aleatório com a não obtenção do resultado desejado; e, enfim, uma incerteza contrafactual, que resulta dos elementos anteriores ${ }^{70}$.

O artigo 186 do Código Civil estabelece a regra da responsabilidade civil subjetiva, segundo a qual se requer, por parte do lesado, a prova da culpabilidade do agente - no caso, o pesquisador. Deve-se provar que este agiu com dolo (intenção de causar dano) ou com culpa, ao ter deixado de fazer o que devia (negligência), ao ter feito o que não devia (imprudência) ou ao ter feito o que não sabia como fazer (imperícia).

No caso de pesquisas com seres humanos, em que há um pesquisador responsável, pesquisadores executantes e outros auxiliares, aquele primeiro sempre responderá pelos atos destes últimos, porque, nos termos do artigo 932 do Código Civil, "são também responsáveis pela reparação civil: [...] III - o empregador ou comitente, por seus empregados, serviçais e prepostos, no exercício do trabalho que lhes competir, ou em razão dele" e, nos termos do artigo 933, "as pessoas indicadas nos incisos I a V do artigo antecedente, ainda que não haja culpa de sua parte, responderão pelos atos praticados pelos terceiros ali referidos". No mesmo sentido, a $\mathrm{CF} / 88$ dispõe que "as pessoas jurídicas de direito público e as de direito privado

\footnotetext{
${ }^{68}$ SILVA, Rafael Peteffi da. Responsabilidade civil pela perda de uma chance. 3.ed. São Paulo: Atlas, 2013. p. 62. ${ }^{69}$ CARNAUBA, Daniel Amaral. Responsabilidade civil pela perda de uma chance: a álea e a técnica. Rio de Janeiro: Forense; São Paulo: Método, 2013. p. 31.

${ }^{70}$ Id. Ibid., p. 39.
} 
prestadoras de serviços públicos responderão pelos danos que seus agentes, nessa qualidade, causarem a terceiros, assegurando o direito de regresso contra o responsável nos casos de dolo ou culpa" (artigo 37, parágrafo $6^{\circ}$ ). Quando a pesquisa for realizada em instituição pública, a responsabilidade civil recairá também sobre as instituições. Nesse caso, a responsabilidade civil é objetiva, isto é, independe da prova de dolo ou de culpa do pesquisador.

Isso não significa que o pesquisador responsável, o pesquisador executante ou qualquer auxiliar estejam isentos do pagamento da indenização por esta ter sido paga pela instituição privada ou pelo Estado. Apenas a lei confere ao participante da pesquisa que tenha sofrido qualquer dano o direito de cobrar indenização também à instituição privada ou ao Estado, porque a solidariedade permite à vitima do dano "receber de um ou de alguns dos devedores, parcial ou totalmente, a dívida comum" (artigo 275, Código Civil). Se a instituição ou o Estado, conforme o caso, pagar a indenização, fica-lhe assegurado o direito de reaver dos causadores do dano ou da equipe de pesquisadores os valores desembolsados para tanto, nos termos do artigo 283 do Código Civil: "[o] devedor que satisfez a dívida por inteiro tem direito a exigir de cada um dos codevedores a sua quota, dividindo-se igualmente por todos a do insolvente, se o houver, presumindo-se iguais, no débito, as partes de todos os codevedores".

Ademais, os patrocinadores da pesquisa também respondem perante o participante, nos termos do artigo 927, parágrafo único, do Código Civil: "Haverá obrigação de reparar o dano, independentemente de culpa, nos casos especificados em lei, ou quando a atividade normalmente desenvolvida pelo autor do dano implicar, por sua natureza, risco para os direitos de outrem". Tendo em vista que o patrocinador é a indústria farmacêutica, que fabrica medicamentos e realiza pesquisas para o desenvolvimento de novas drogas, tudo isso é considerado atividade que coloca em risco os direitos de outrem e, portanto, fica sujeita, solidariamente, à reparação dos danos, ainda que $\mathrm{o}$ ato tenha sido causado pelos pesquisadores.

O conteúdo da indenização também é previsto no Código Civil:

Art. 948. No caso de homicídio, a indenização consiste, sem excluir outras reparações: I - no pagamento das despesas com o tratamento da vítima, seu funeral e o luto da família; II - na prestação de alimentos às pessoas a quem o morto os devia, levando-se em conta a duração provável da vida da vítima;

Art. 949. No caso de lesão ou outra ofensa à saúde, o ofensor indenizará o ofendido das despesas do tratamento e dos lucros cessantes até o fim da convalescença, além de algum outro prejuízo que o ofendido prove haver sofrido; 
Art. 950. Se da ofensa resultar defeito pelo qual o ofendido não possa exercer o seu ofício ou profissão, ou se lhe diminua a capacidade de trabalho, a indenização, além das despesas do tratamento e lucros cessantes até o fim da convalescença, incluirá pensão correspondente à importância do trabalho para que se inabilitou, ou da depreciação que ele sofreu. Parágrafo único. O prejudicado, se preferir, poderá exigir que a indenização seja arbitrada e paga de uma só vez;

Art. 951. O disposto nos arts. 948, 949 e 950 aplica-se ainda no caso de indenização devida por aquele que, no exercício de atividade profissional, por negligência, imprudência ou imperícia, causar-lhe a morte do paciente, agravar-lhe o mal, causar-lhe lesão, ou inabilitá-lo para o trabalho.

Como a responsabilidade civil independe da responsabilidade criminal, nos termos do artigo 935 do Código Civil, o pesquisador poderá responder pessoalmente pelos crimes de homicídio doloso (artigo 121, Código Penal), homicídio culposo (artigo 121, parágrafos $3^{\circ}$ e $4^{\circ}$, Código Penal), aborto (artigos 125, 126 e 127, Código Penal), lesão corporal (artigo 129, caput e parágrafos $1^{\circ}$ a $8^{\circ}$, Código Penal) e violação de segredo profissional (artigo 154, Código Penal).

Por fim, a pretensão do participante de pesquisas médicas à reparação de quaisquer danos cometidos pelos pesquisadores está sujeita a prazos prescricionais. No caso, aplica-se aos pesquisadores e a instituições privadas o disposto no artigo 206, parágrafo $3^{\circ}$, do Código Civil, que afirma que prescrever "Em três anos: [...] V - a pretensão de reparação civil". Quando a pretensão à indenização for proposta contra o Estado, o prazo prescricional é de cinco anos, nos termos do artigo $1^{\circ}$ do Decreto n. 20.910/1932 $2^{71}$.

\section{Considerações finais}

A disciplina ética a respeito das pesquisas com seres humanos está diretamente interligada com o Código Civil. Em razão de sua especificidade, como também da falta de juridicidade da Declaração de Helsinque e da natureza infralegal da Resolução CNS n. 466/2012, esses diplomas normativos não poderiam contemplar assuntos relacionados à personalidade jurídica, à capacidade de agir, aos direitos da personalidade e à responsabilidade civil. Por sua vez, o Código Civil, em razão de sua generalidade, não poderia contemplar, detalhadamente, aspectos específicos relacionados às pesquisas com seres humanos. No entanto, pesquisadores devem conhecer as regras contidas no Código Civil, uma vez que não estão imunes a sua incidência. É o Código Civil que dará a eficácia necessária àqueles documentos normativos, que, em última análise, voltam-se à proteção da pessoa humana.

\footnotetext{
${ }^{71}$ BRASIL. Decreto n. 20.910, de 06 de janeiro de 1932. Regula a prescrição quinquenal. Disponível em: <http://www.planalto.gov.br/ccivil_03/decreto/Antigos/D20910.htm>. Acesso em: 22 set. 2015.
} 
As pesquisas com seres humanos devem respeitar os direitos da personalidade - como a vida, a integridade física e a integridade psíquica -, os quais são direitos indisponíveis. Mesmo em um cenário de flexibilização de regras éticas, como se verifica nas sucessivas modificações da -, não há como o pesquisador eximir-se da responsabilidade civil em caso de lesões aos direitos da personalidade ocasionados aos participantes de uma pesquisa, além das sanções aplicáveis pelos CEPs.

\section{Referências}

ALVES, José Carlos Moreira. Direito romano. 14. ed. Rio de Janeiro: Forense, 2007.

ARAUJO, Diego Vinicius Pacheco de. A caracterização do analfabetismo funcional em usuários do Hospital das Clínicas da Faculdade de Medicina da Universidade de São Paulo: recomendações para a redação do termo de consentimento livre e esclarecido. Dissertação (Mestrado) - Escola de Enfermagem da Universidade de São Paulo, São Paulo, 2009.

BITTAR, Carlos Alberto. Os direitos da personalidade. 5. ed. atual. e aum. por Eduardo C. B. Bittar. Rio de Janeiro: Forense Universitária, 2001.

CARNAUBA, Daniel Amaral. Responsabilidade civil pela perda de uma chance: a álea e a técnica. Rio de Janeiro: Forense; São Paulo: Método, 2013.

DE CUPIS, Adriano. Os direitos da personalidade. 2. ed. São Paulo: Quorum, 2008.

FERREIRA RUBIO, Delia Matilde. El derecho a la intimidad: análisis del artículo 1071 bis del Código Civil a la luz de la doctrina, la legislación comparada y la jurisprudencia. Buenos Aires: Editorial Universidad, 1982.

GARRAFA, Volnei. Declaración de Helsinki y sus repetidos 'ajustes': un tema fatigoso. Revista Lassalista de Investigación, Caldas, v. 11, n. 1, p. 35-40, jan./jun. 2014. Disponível em: <http:// www.scielo.org.co/pdf/rlsi/v11n1/v11n1a04.pdf>. Acesso em: 22 set. 2015.

; LORENZO, Claudio. Helsinque 2008: redução da proteção e maximização de interesses privados. Revista da Associação Médica Brasileira, São Paulo, v. 55, n. 5. p. 514-518, set./out. 2009. Disponível em: <http://repositorio.unb.br/bitstream/10482/12650/1/ARTIGO_ Helsinque2008Reducao.pdf $>$. Acesso em: 21 set. 2015.

GOGLIANO, Daisy. O consentimento informado em matéria de bioética: ilusão de exclusão de responsabilidade. Revista da Faculdade de Direito da Universidade de São Paulo, v. 104, p. 509-547, jan./dez. 2009. Disponível em: <http://www.revistas.usp.br/rfdusp/article/ view/67868>. http://dx.doi.org/10.11606/issn.2318-8235.v104i0p509-547.

KOTTOW, Miguel. De Helsinki a Fortaleza: una Declaración dessangrada. Revista Bioética. Brasília, v. 22, n. 1. p. 28-33, abr. 2014. Disponível em: <http://revistabioetica.cfm.org.br/ index.php/revista_bioetica/article/view/880/969>. Acesso em: 22 set. 2015. 
LOBATO, L.; CAÇADOR, B.; GAZZINELLI, M. Legibilidade dos termos de consentimento livre e esclarecido em ensaios clínicos. Revista Bioética, Brasília, v. 21, n. 3, p. 557-565, dez. 2013. Disponível em: <http://www.scielo.br/pdf/bioet/v21n3/a20v21n3.pdf>. http://dx.doi. org/10.1590/S1983-80422013000300020.

MILLUM, J; WENDLER, D; EMANUEL, E.J. The 50th Anniversary of the Declaration of Helsinki: progress but many remaining challenges. JAMA, v. 310, n. 20, p. 2143-2144, 27 nov. 2013. Disponível em: $<$ http://jama.jamanetwork.com/article.aspx?articleID=1760320 $>$. doi:10.1001/jama.2013.281632.

NUREMBERG MILITARY TRIBUNALS. Trials of War Criminals before the Nuremberg Military Tribunals under Control Council Law n. 10. Volume II - "The medical case", "The Milch Case”. Washington: Superintendent of Documents. U.S. Government Printing Office. 1949. P. 5; 14; 182-183; 193-197. Disponível em: <http://www.loc.gov/rr/frd/Military_Law/ pdf/NT_war-criminals_Vol-II.pdf >. Acesso em: 22 set. 2015.

SCHLEMPER JUNIOR, Bruno Rodolfo. O placebo e a Declaração de Pachuca: letras mortas? Revista Bioética, Brasília, v. 22, n. 1. p. 462-470. Disponível em: <http://www.scielo.br/pdf/ bioet/v22n3/v22n3a10.pdf>. http://dx.doi.org/10.1590/1983-80422014223029.

SILVA, Rafael Peteffi da. Responsabilidade civil pela perda de uma chance. 3.ed. São Paulo: Atlas, 2013.

Eduardo Tomasevicius Filho - Doutor em Direito Civil pela Universidade de São Paulo. Professor Doutor do Departamento de Direito Civil da Faculdade de Direito da Universidade de São Paulo. São Paulo/SP, Brasil.E-mail: tomasevicius@usp.br. 